\title{
Behcet's disease presenting with pulmonary thromboembolism
}

\author{
Seray ABUZAINA ${ }^{1}$ (ID) \\ Sevil PEMPECi ${ }^{1}($ ID) \\ Emine ARGÜDER ${ }^{1}$ (ID) \\ Ayşegül KARALEZLi ${ }^{1}$ (ID) \\ H. Canan \\ HASANOĞLU ${ }^{1}$ (ID)
}

\author{
${ }^{1}$ Department of Chest Diseases, Faculty of Medicine, Yildirim Beyazit \\ University, Ankara, Turkey \\ ${ }^{1}$ Yıldırım Beyazıt Üniversitesi Tıp Fakültesi, Göğüs Hastalıkları Anabilim Dalı, \\ Ankara, Türkiye
}

Cite this article as: Abuzaina S, Pempeci $S$, Argüder $E$, Karalezli A, Hasanoğlu HC. Behcet's disease presenting with pulmonary thromboembolism. Tuberk Toraks 2020;68(3):337-341.

Yazışma Adresi (Address for Correspondence)

\section{Dr. Seray ABUZAINA}

Yıldırım Beyazıt Üniversitesi Tıp Fakültesi, Göğüs Hastalıkları Anabilim Dalı, ANKARA - TÜRKIYE

e-mail: dr.seraybildir@hotmail.com

\footnotetext{
CCopyright 2020 by Tuberculosis and Thorax.
}

Available on-line at www.tuberktoraks.org.com

\begin{abstract}
Behcet's disease presenting with pulmonary thromboembolism

Behcet's disease is a chronic inflammatory multi-systemic vasculitis. Recurrent oral and genital aphthous ulcers, uveitis, arthritis, arterial aneurysms, venous thrombosis, gastrointestinal system lesions and skin lesions can be seen. Large, medium or small arteries and veins may be involved. While venous lesions cause occlusion, arterial lesions can cause both occlusion and aneurysm. Major forms of pulmonary involvement include pulmonary artery aneurysm, arterial and venous thrombosis, pulmonary infarction, recurrent pneumonia, and pleurisy. In Behcet's disease, pulmonary thromboembolism $(P E)$ is often associated with endothelial damage. Neutrophils play an important role in the pathogenesis of thrombosis. Coagulation components such as fibrinogen, thrombin, factor Xa and factor VIla activate the inflammatory cascade and induce vascular events. It is important to understand the pathogenesis of vascular events in determining the effective treatment strategy. Here we present a patient with Behcet's disease who was presented with pulmonary embolism and was investigated for the etiology of thrombosis.
\end{abstract}

Key words: Anticoagulantion; Behcet's disease; thromboembolism

Öz

Pulmoner tromboemboli ile prezente olan Behçet hastalığı

Behçet hastalığı, kronik inflamatuar multi-sistemik bir vaskülittir. Tekrarlayan oral ve genital aftöz ülserler, üveit, artrit, arteriyel anevrizmalar, venöz trombozlar, gastrointestinal sistem lezyonları ve cilt lezyonları görülebilir. Büyük, orta veya küçük arter ve venler tutulabilir. Venöz lezyonlar oklüzyona neden olurken, arteriyel lezyonlar hem oklüzyon hem de anevrizmaya neden olabilir. Başlıca pulmoner tutulum şekilleri arasında, pulmoner arter anevrizması, arteriyel ve venöz trombozlar, pulmoner infarkt, tekrarlayan pnömoni ve plöreziler yer alır. Behçet hastalığında, pulmoner tromboembolizm sıklıkla endotel hasarı ile ilişkilidir. Tromboz patogenezinde nötrofiller önemli bir role sahiptir. Fibrinojen, trombin, faktor Xa ve faktor VIla gibi koagülasyon bileşen- 
leri enflamatuar kaskadı aktifleştirir ve vasküler olayları tetikler. Etkili tedavi stratejisinin belirlenmesinde vasküler olayların patogenezini anlamak önemlidir. Burada pulmoner emboli ile prezente olan ve tromboz etiyolojisi araştırılırken Behçet hastalığı tanısı konan bir hasta sunulmuştur.

Anahtar kelimeler: Antikoagülasyon; Behçet hastalığı; tromboemboli

\section{INTRODUCTION}

Behcet's disease was described by Hulusi Behçet, a Turkish dermatologist in 1973, with the trilogy of: oral aphthous ulcers, genital ulcers, and eye symptoms. Nowadays, it is known that this disease does not consist solely of these three findings. It's systemic disease which may cause uveitis, arthritis, recurrent oral and genital aphthous ulcers, arterial aneurysms, skin lesions, venous thrombosis and gastrointestinal lesions (1).

In Behcet's disease, venous involvement is more common than arterial involvement (2). Venous involvement is more commonly seen in superficial thrombophlebitis or deep vein thrombosis (DVT) and it is more common in men (3). Pulmonary artery thrombosis and pulmonary artery aneurysms are seen in the lungs. Pulmonary artery aneurysms are rare, but it's ruptured may cause pulmonary hemorrhage and hemoptysis (4). Although pulmonary artery aneurysms are less common, they should be treated correctly because of high morbidity and mortality risk. Since anticoagulant therapy may cause massive hemoptysis in the presence of pulmonary artery aneurysm, the use of anticoagulant drugs in the treatment of thrombosis in Behcet's disease is controversial $(5,6)$. Herein, we present a patient with pulmonary thromboembolism (PTE) who was diagnosed with Behcet's disease in further investigations.

\section{CASE REPORT}

A forty-six-year-old male patient presented to the emergency department because of sudden onset of back pain and about 10-15 cc/day hemorrhagic sputum. Her past medical history revealed an operation history due to papillary carcinoma of the thyroid and hypertension. A history of 20 packets/year smoking (15 years of abandonment) and biomass exposure were found. He had a family history of laryngeal carcinoma.

In the physical examination; The respiratory rate was $30 / \mathrm{min}$, blood pressure was 110/65 $\mathrm{mmHg}$, pulse was $105 / \mathrm{min}$, oxygen saturation in the room air $\left(\mathrm{SpO}_{2}\right)$ was $94 \%$. Respiratory and cardiovascular sys- tem examination was normal. Wells score was 5.5. Electrocardiography revealed sinus tachycardia. In the arterial blood gas collected in the room air, $\mathrm{pH}$ was $7.48 \mathrm{mmHg}, \mathrm{PaO}_{2}: 65 \mathrm{mmHg}, \mathrm{PaCO}_{2}: 30$ $\mathrm{mmHg}$, and oxygen saturation was 92\%. D-dimer was $11.9 \mu \mathrm{g} / \mathrm{mL}$ (a rapid automated quantitative latex-based immuno-agglutination assay was used). In the postero-anterior (PA) chest X-ray the left hemidiaphragm was elevated, and there was a nonhomogeneous opacity increase in the left lower zone (Figure 1). Thoracic computed tomography (CT) angiography was taken because of the suspesion of PE revealed a filling defect in the left lower lobar and segmental pulmonary arteries, consistent with an infarct area at the periphery (Figure $2 \mathrm{a}$ and $2 \mathrm{~b}$ ). Low molecular weight heparin (LMWH) was initiated as anticoagulant therapy. Echocardiography showed normal right heart cavities, the systolic pulmonary artery pressure (s-PAP) was $29 \mathrm{mmHg}$. Troponin-T and pro-BNP were at normal range. In both upper and lower extremity venous doppler ultrasonography, thrombosis was observed in both antecubital veins. In order to reveal the etiology, the risk factors were investigated and no obvious risk factors were found in the history of the patient for PTE development, but because of erythema nodosum-like lesions on the lower extremity

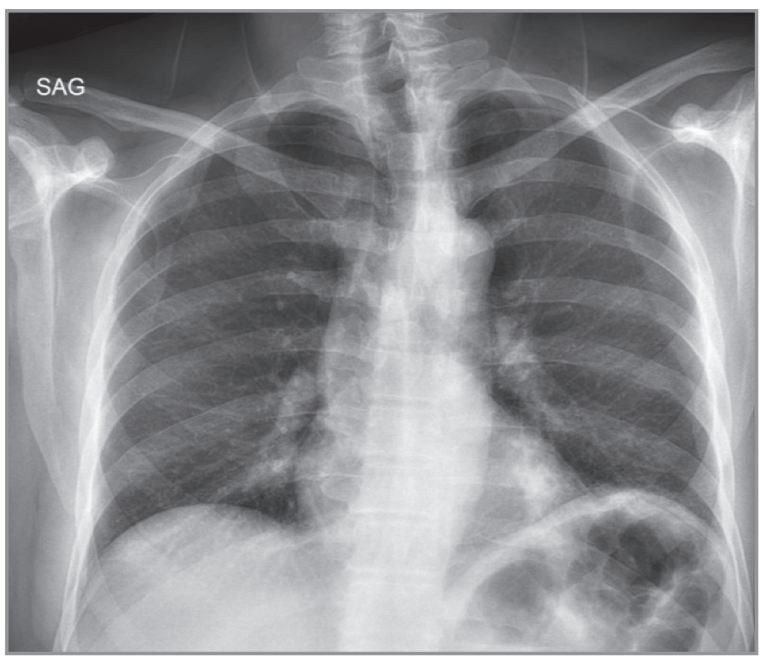

Figure 1. Elevation of the left hemidiaphragm and increase in nonhomogeneous opacity in left lower zone in the PA chest X-ray. 

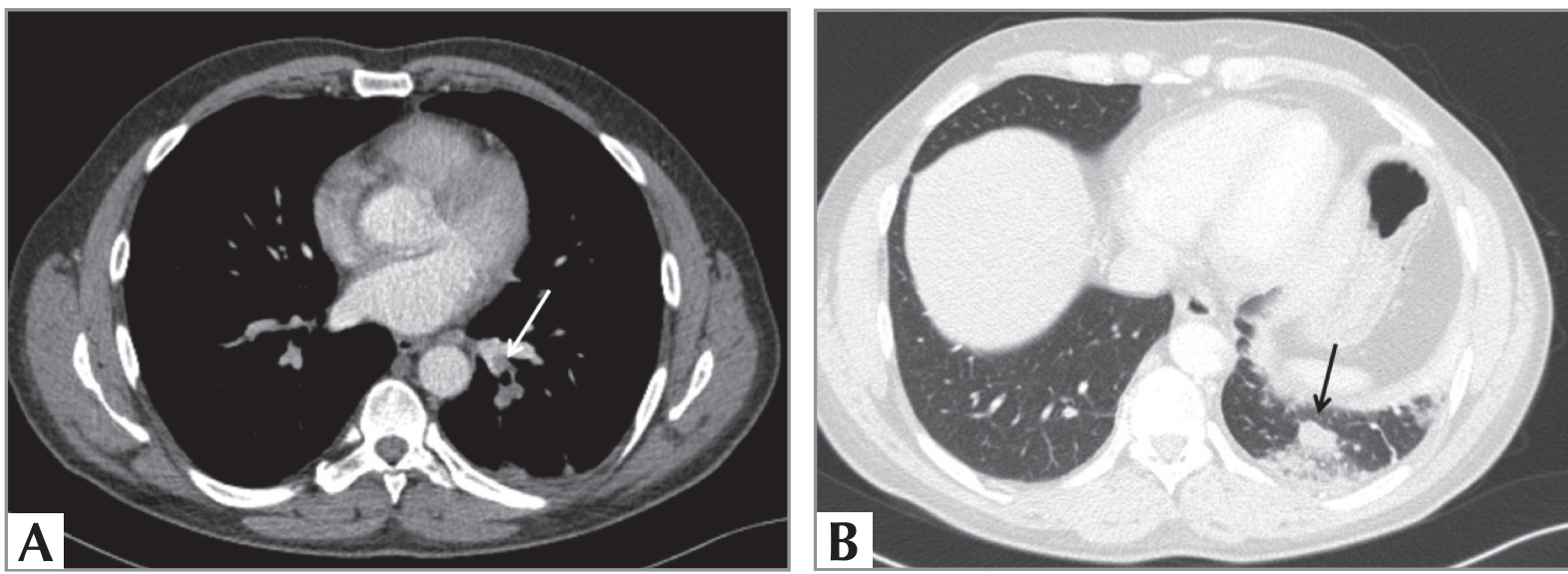

Figure 2. A. Hypodense filling defects in the left lower lobar posterior and lateral segmental pulmonary arteries in the pulmonary CT angiography mediastinum window, B. Pleural based infarct at the posterior of the left lower lobe in the pulmonary CT

extensor facies and the history of recurrent oral aphthae, the patient was cosulted by Dermatology Department with the prediagnosis of Behcet's disease. The ophthalmic examination was normal. The HLA-B51/52 was positive. The patient started to be followed up by dermatology, with the diagnosis of Behcet's disease because of the development of thrombosis in the superficial veins and pulmonary artery and the positive result of the genetic test. Colchicine treatment was commenced. Factor $\mathrm{V}$ leiden and MTHFR heterozygote and PAI-1 4G/5G polymorphism were detected in the patient's thrombophilia panel. An anticoagulation treatment with apiksaban carried on. Thoracic CT angiography was performed 6 months later. No aneurysm or intracardiac thrombus was detected. There was no re-thrombus in the upper extremity venous doppler control. Because the factor $V$ Leiden mutation was heterozygous, the anticoagulant therapy was continued and terminated after 1 year, whereas the Colchicine continued. No complication was observed during follow-up.

\section{DISCUSSION}

Behcet's disease is a multi-systemic disease that can involve pulmonary, neurological, gastrointestinal, genitourinary, skin and vascular system. The disease usually begins in the third decade, and rarely seen after 50 years old or in childhood. While both genders are equally affected, the disease is more severe in male sex and adolescents (1).

The diagnosis of Behcet's disease is determined by clinical symptoms. The diagnostic criteria for Behcet's disease vary between countries and researchers. The
International Study Group FOR Behcet's Disease (ISG) developed the simplified ISG criteria by analyzing the specificity and sensitivity of the five diagnostic criteria. Recurrent oral ulcers were classified as major criterion, recurrent genital ulcers, typical ocular lesions, typical skin lesions, and positive skin pathergy test as minor criteria. Behcet's disease can be diagnosed in the presence of a major and two minor criteria according to these criteria (7). The International Criteria for Behcet Disease (ICBD) is a separate diagnostic criterion for Behcet's disease. According to these criteria, ocular lesions are evaluated as 2 points, oral aphthae 2 points, genital aft 2 points, skin lesions 1 point, central nervous system lesions 1 point, vascular lesions 1 point and skin pathergy test positivity 1 point. With a total score of 4 or more, Behcet's disease is diagnosed (8). The score of our patient was 4 points. HLA-B51 or HLA-A26 positivity is considered to be useful in clinical practice but is not a diagnostic criterion.

Vascular involvement is one of the most important features of Behcet's disease. Vascular vessels of all sizes, from capillaries to large vessels. Venous symptoms can be seen in the form of superficial phlebitis, deep vein thrombosis and even large vessel thrombosis (eg vena cava). Arterial findings are thrombosis and aneurysms. Pulmonary aneurysm is one of the main causes of death in Behcet's disease (8).

Superficial venous thrombosis (DVT) and deep vein thrombosis (DVT) are the most common types of vascular involvement. It is seen in $15-40 \%$ of patients with Behcet's disease. In our case, thrombosis was found in the superficial veins of the upper extremity. 
In severe cases, deep vein thrombosis can be seen in both upper and lower extremity veins as a late complication of post-thrombotic syndrome. Thrombosis of atypical areas is also an important feature of Behcet's disease. In patients with inferior and superior vena cava, Budd-Chiari syndrome, suprahepatic veins, portal vein, cerebral sinuses and right ventricle are the main venous thrombosis sites. Arterial involvement is rarely seen compared with venous involvement. Behcet's patients should be investigated about arterial aneurysms (6).

Pulmonary artery aneurysm is the most common form of pulmonary involvement in patients with Behcet's disease and the most common cause of mortality is massive hemoptysis due to pulmonary artery aneurysm (4). However, pulmonary arterial and venous thrombosis, pulmonary infarction, recurrent pneumonia and pleurisy can be seen. In Behcet's disease, the development of thrombus in the pulmonary artery occurs in the form of in-situ thrombosis associated with endothelial injury. Neutrophils and inflammation play a role in the pathogenesis of thrombotic events. Neutrophil activation has been shown to promote thrombus formation by causing fibrinogen oxidation (9). In addition, cytokines such as IL-1, IL-6, IL-17, TNF-alpha and CXCL8 also play a role in the pathogenesis (6).

There are different opinions about the use of anticoagulant drugs in the treatment of venous thrombosis in Behcet's disease. Some researchers argue that thrombosis develops due to inflammation in the vascular wall in Behcet's disease and therefore only immunosuppressive therapies should be preferred for anticoagulant therapy to suppress inflammation. It is thought that thrombi are usually organized and therefore anticoagulant therapy may lead to worsening of hemoptysis (10). In a study comparing the immunosuppressive therapy and anticoagulant therapy in patients with Behcet's disease accompanied by venous thrombosis, the patients were examined into three groups according to the treatment they received, immunosuppressive and anticoagulant therapy combined, immunosuppressive only and anticoagulant therapy only. There was less recurrence of venous thrombosis in the group treated with immunosuppressive and anticoagulation, but no statistically significant difference was found compared with the group that received only immunosuppressive therapy (11). In our case we commenced anticoagulant ther- apy for a year because of the presence of thrombus in the pulmonary artery as well as the genetic predisposition to thrombophilia in our patient. In some cases, anti-TNF agents have been shown to be useful in the treatment of pulmonary vasculitis (12).

Another approach is to screen each Behcet's disease patient for genetic markers (factor $\mathrm{V}$ Leiden, prothrombin gene, protein $\mathrm{C}$, protein $\mathrm{S}$, antithrombin and anticardiolipin antibody) that may be susceptible to thrombosis and to add anticoagulant therapy to immunosuppressive therapy in patients with a marker that facilitates thrombosis (13). Factor $\mathrm{V}$ leiden heterigot mutant was detected in our case. In addition, if warfarin is used in anticoagulant therapy, the potential drug-drug interaction should be considered (14). Although it is rare in Behcet's disease, intracardiac thrombus may occur. In these cases, there are studies suggesting the combination of anticoagulant therapy and immunosuppressive therapy (15).

As a result, Behcet's disease may occur with pulmonary artery involvement. It should be kept in mind that Behcet's disease is one of the reasons that should be considered in young patients with PE who are not considered to have any risk factors for PE.

\section{CONFLICT of INTEREST}

The authors reported no conflict of interest related to this article.

\section{AUTHORSHIP CONTRIBUTIONS}

Concept/Design: SA, EA

Analysis/Interpretation: SA, EA, SP

Data Acquisition: SA, SP

Writting: SA

Critical Revision: EA, $\mathrm{HCH}, \mathrm{AK}$

Final Approval: EA, $\mathrm{HCH}, \mathrm{AK}$

\section{REFERENCES}

1. Yurdakul S, Hamuryudan V, Fresko I, et al. Behcet's syndrome. In: Hochberg MC, Silman AJ, Smolen YS, et al (eds). Rheumatology. $5^{\text {th }}$ ed. Philadelphia: Mosby Elsevier, 2011: 1575-81.

2. Dinç A. Behcet hastalığında vasküler tutulum ve tedavisi. Turkiye Klinikleri I Dermatol-Special Topics 2011; 4(4): 66-72.

3. Ishibashi H. What is vascular Behcet's disease? Ann Vasc Dis 2018; 11(1): 52-6 
4. Seyahi E. Behcet's disease: How to diagnose and treat vascular involvement. Best Pract Res Clin Rheumatol 2016; 30(2): 279-95.

5. Merashli M, Eid RE, Uthman I. A review of current management of vasculo-Behcet's. Curr Opin Rheumatol 2018; 30(1): 50-6.

6. Emmi G, Bettiol A, Silvestri E, Di Scala G, Becatti $M$, Fiorillo $C$, et al. Vascular Behcet's syndrome: an update. Intern Emerg Med 201; 14(5): 645-52.

7. Davatchi F, Assaad-Khalil S, Calamia KT, et al. The international criteria for Behcets disease: a collaborative study of 27 countries on the sensitivity and specificity of the new criteria. J Eur Acad Dermatol Venereol 2014; 28: 338-47.

8. Davatchi F, Chams-Davatchi C, Shams H, Shahram F, Nadji A, Akhlaghi M, et al. Behcet's disease: epidemiology, clinical manifestations, and diagnosis. Expert Rev Clin Immunol 2017; 13(1): 57-65.

9. Becatti M, Emmi G, Bettiol A, Silvestri E, Di Scala G, Taddei $N$, et al. Behcet's syndrome as a tool to dissect the mechanisms of thrombo-inflammation: clinical and pathogenetic aspects. Clin Exp Immunol 2018; 195(3): 322-33.

10. Uzun O, Akpolat T, Erkan L. Pulmonary vasculitis in Bechet disease: a cumulative analysis. Chest 2005; 127(6): 2243-53.
11. Ahn JK, Lee YS, Jeon CH, Koh EM, Cha HS, Treatment of venous thrombosis associated with Behcet's disease: immunosuppressive therapy alone versus immunosuppressive therapy plus anticoagulation. Clin Rheumatol 2008; 27: 201-5.

12. Khabbazi A, Ebrahimi A, Ebrahimi F, Esmaeil HM. Complete resolution of pulmonary artery aneurysm in a patient with Behcet's disease with infliximab. JCRP 2016; 4(3): 32-3.

13. Korkmaz C. Is anticoagulation unnecessary in Behcet's disease with deep venous thrombosis? Clin Rheumatol 2008; 27: 405-6.

14. Vazquez $S R$, Rondina MT, Pendleton RC. Azathioprineinduced warfarin resistance. Ann Pharmacother 2008; 42: 1118-23.

15. SM Dogan, A Birdane, C Korkmaz, N Ata, B Timuralp. Right ventricular thrombus with Behcet's syndrome: Successful treatment with warfarin and immunosuppressive agents. Tex Heart Inst J 2007; 34(3) :360-2. 